\title{
Biochemical detection of E-ADA on Neospora caninum tachyzoites and the effects of a specific enzymatic inhibitor
}

\author{
Detección bioquímica de E-ADA en taquizoitos de Neospora \\ caninum y los efectos de un inhibidor enzimático específico
}

\author{
Alexandre A. Tonin, ${ }^{1 *}$ Ph.D, Aleksandro S. Da Silva, ${ }^{2}$ Ph.D, Victor C. Pimentel, ${ }^{3}$ Ph.D, \\ Daniele Zanini, ${ }^{3}$ Ph.D, Maria Rosa C. Schetinger, ${ }^{3}$ Ph.D, Vera M. Morsch, ${ }^{3}$ Ph.D, Giovana \\ Camillo, ${ }^{4}$ M.Sc, Fernanda S.F. Vogel, ${ }^{4}$ Ph.D, Sonia T.A. Lopes,${ }^{1}$ Ph.D.
}

\begin{abstract}
${ }^{1}$ Universidade Federal de Santa Maria, Departamento de Clínica de Pequenos Animais, Santa Maria, Brasil. 'Universidade do Estado de Santa Catarina, Departamento de Zootecnia, Chapecó, Brasil. ${ }^{3}$ Universidade Federal de Santa Maria, Departamento de Química, Santa Mria, Brasil. ${ }^{4}$ Universidade Federal de Santa Maria, Departamento de Medicina Veterinária Preventiva, Santa Maria, Brasil. *Correspondence: tonin.aat@gmail.com
\end{abstract}

Received: April 2014; Accepted: October 2014.

\begin{abstract}
Objective. This study aimed to investigate the presence and activity of the ecto adenosine deaminase (E-ADA) enzyme in tachyzoites of Neospora caninum (Nc-1 strain), as well as to assess the activity of a well-known E-ADA inhibitor, the deoxycoformycin. Materials and methods. The parasites were grown in cell culture, being subsequently separated in a pellet of tachyzoites, on which the E-ADA activity was tested using the concentrations 0 (control), $0.2,0.4$ and $0.8 \mathrm{mg} \mathrm{mL}^{-1}$. Results. The E-ADA showed high activity, progressively increasing its activity according to the enhancement of the protein concentration. The test was carried out with different concentrations of deoxycoformycin, showing that it was able to inhibit the E-ADA present on the free form of the parasite. Conclusions. Based on these results we conclude that the E-ADA is present on tachyzoites of $N$. caninum, and deoxycoformycin is able to inhibit this enzyme. In this sense, knowing the negative impact of $N$. caninum on reproductive issue in cattle (mainly abortion), might it is an alternative in order to deal with this parasitic infection.
\end{abstract}

Key words: adenosine deaminase, deoxycoformycin, neosporosis (Source: $C A B, M e S H$ ).

\section{RESUMEN}

Objetivo. Este estudio tuvo como objetivo investigar la presencia y la actividad de la adenosina deaminasa (E-ADA) en taquizoitos de Neospora caninum (Nc-1 cepa), así como ensayar un conocido inhibidor de estas enzimas. Material y métodos. Los parásitos se multiplicaron en cultivo celular y posteriormente fueron separados en un sedimento de taquizoitos. La actividad de E-ADA fue probada en el parásito, usando concentraciones de 0 (control), $0.2,0.4$ y $0.8 \mathrm{mg} \mathrm{mL}^{-1}$. Resultados. El E-ADA tenía una alta actividad aumentó progresivamente de acuerdo con la concentración de proteínas. La prueba se llevó a cabo con diferentes concentraciones del inhibidor E-ADA (desoxicoformicina) y fue 
capaz de inhibir la presente E-ADA en el parásito. Conclusiones. Por la observación de los resultados se concluye que la enzima E-ADA está presente en taquizoítos de $N$. caninum, y desoxicoformicina es capaz de inhibir la acción de la enzima. En este sentido, conocer el impacto negativo del parásito en los problemas productivos y reproductivos en el ganado (principalmente abortos), estos resultados pueden ser una alternativa para envitar esta enfermedad parasitaria.

Palabras clave: adenosina deaminase, desoxicoformicina, neosporosis (Fuente: $C A B, M e S H$ ).

\section{INTRODUCTION}

Neospora caninum (N. caninum) is an obligate, intracellular, coccidian, protozoan parasite of the phylum Apicomplexa (1). Infection by $N$. caninum can cause the clinical disease known as neosporosis, which most notably presents itself as abortion in cattle (2). The main form of $N$. caninum that causes the acute infection in the intermediate host is the tachyzoite (3). At the early stage of infection, tachyzoites probably modulate host cell functions, while late stages probably are targeted for destruction by the host, diminishing their pathogenicity (4-6). The biological cycle of $N$. caninum is very similar to the one generated by Toxoplasma gondii $(1,7)$. Literature has described different proteins (mainly belonging to kinase's family) as a regulator of the biological cycle of $T$. gondii (8), as well as it can occur in $N$. caninum. The effective treatment of neosporosis is unknown, thus proteins and enzymes present in the parasite may became a parallel line of studies, in order to test inhibitors as an alternative way for treatment.

The purinergic system, between various components, presents the enzyme ecto adenosine deaminase (E-ADA). E-ADA is considered to be a key enzyme in the purine metabolism, catalyzing the irreversible deamination of adenosine and deoxyadenosine to inosine and deoxyinosine, respectively, and closely regulating extracellular adenosine and inosine concentrations $(9,10)$. In this sense, 2'-Deoxycoformycin, a potent inhibitor of E-ADA, is increasingly used as a tool to investigate adenosine metabolism (10). However, on $N$. caninum, E-ADA has not been studied yet, becoming the main purpose of this study. Thus, the aim of this study was to investigate the presence and the activity of E-ADA on $N$. caninum tachyzoites, as well as to assess the effects of deoxycoformycin on the activity of this enzyme.

\section{MATERIAL AND METHODS}

Local. The experiment was conducted at the Laboratory of Animal Parasitology, at Universidade Federal de Santa Maria, city of Santa Maria, Brazil.

\section{INTRODUCCIÓN}

El Neospora caninum (N. caninum) es un parásito obligado, intracelular, coccidio, protozoo del phylum Apicomplexa (1). Las infecciones de $N$. caninum puede conllevar a la enfermedad clínica conocida como neosporosis, que se presenta principalmente durante el aborto en bovinos (2). La forma principal de $N$. caninum que causa la infección aguda en el huésped intermediario es el taquizoíto (3). En las etapas tempranas de la infección, los taquizoítos modulan probablemente la funciones de la célula huésped, mientras que en las etapas finales son probablemente destruidos por el anfitrión, disminuyendo su patogenicidad (4-6). El ciclo biológico de $N$. caninum es muy similar a aquel generado por Toxoplasma gondii (1.7). En la literatura se han descrito diferentes proteínas (principalmente pertenecientes a la familia de quinasas) como un regulador del ciclo biológico de $T$. gondii (8), así como puede presentarse en $N$. caninum. No existe un tratamiento efectivo conocido para la neosporosis, de forma que las proteínas y enzimas presentes en el parásito pueden convertirse en una línea paralela de estudios para poner a prueba los inhibidores como un tratamiento alternativo.

La adenosina desaminasa (E-ADA) se presenta en el sistema purinérgico, entre varios componentes. Se considera que la E-ADA es una enzima clave en el metabolismo de la purina, catalizando la desaminación irreversible de la adenosina y desoxiadenosina a inosina y deoxinosina, respectivamente y regulando estrechamente las concentraciones extracelulares de adenosina e inosina $(9,10)$. En este sentido, la 2'-Deoxicoformicina, un inhibidor potente de E-ADA, es utilizada cada vez más como una herramienta para investigar el metabolismo de la adenosina (10). Sin embargo, la E-ADA no ha sido estudiado aún en $N$. caninum, convirtiéndose en el objetivo principal de este estudio. Por lo tanto, el objetivo de este estudio fue investigar la presencia y la actividad de E-ADA en los taquizoítos de $N$. caninum, así como evaluar los efectos de la deoxicoformicina en la actividad de esta enzima. 
Neospora caninum isolate. Neospora caninum tachyzoites (NC-1 isolate) were maintained by continuous passage in Vero cell culture, using standard procedures. Parasites were harvested from tissue culture, and viability was determined by trypan blue exclusion (11), followed by counting three aliquots in a Neubauer chamber. For inoculation, organisms were adjusted to the appropriate concentration ( $1 \times 10^{6}$ tachyzoites/ $\mathrm{mL}$ ). Tachyzoites were washed three times in PBS, adjusted at $\mathrm{pH} 7.4$ and NC- 1 tachyzoites were separated into pellets for E-ADA analysis.

Preparation of tachyzoites. The pellet of tachyzoites was resuspended in $50 \mathrm{mmol} / \mathrm{L}$ per $\mathrm{mM}$ of phosphate buffer; $\mathrm{pH} 6.5$ in order to measure the E-ADA activity. The protein concentration of the tachyzoites was measured by the method of Bradford (12) with bovine serum albumin used as the standard. The concentration of proteins in the parasite was expressed as $\mathrm{mg} \mathrm{mL}^{-1}$.

E-ADA activity in tachyzoites. To measure the E-ADA activity in tachyzoites of $N$. caninum, it was used the technique described to evaluate the E-ADA activity on trypomastigotes forms of Trypanosoma evansi (13). In this sense, E-ADA activity was measured spectrophotometrically on tachyzoites of $N$. caninum through the modified method of Guisti and Galanti (14). The enzymatic reaction was started by addition of $500 \mu \mathrm{L}$ of $21 \mathrm{mmol} / \mathrm{L}$ adenosine as substrate, and it was incubated for $1 \mathrm{~h}$ at $37^{\circ} \mathrm{C}$. The reaction was stopped by adding $1.5 \mathrm{ml}$ of $106 / 0.16 \mathrm{mM}$ phenol-nitroprusside to the reaction mixture, which was immediately mixed with $1.5 \mathrm{ml}$ of 125/11 mM alkaline-hypochlorite (sodium hypochlorite) and vortexed. The ammonia released would react with alkaline-hypochlorite and phenol in the presence of a catalystsodium nitroprusside to produce indophenol (a blue color) and the concentration of ammonia is directly proportional to the absorbance of indophenol read at $620 \mathrm{~nm}$. Ammonium sulfate of $75 \mu \mathrm{M}$ was used as ammonium standard. The specific activity is reported as $\mathrm{U} / \mathrm{mg}$ of protein. The estimation was performed in triplicate.

Tests with E-ADA inhibitor: deoxycoformycin. For this test it was evaluated the action of deoxycoformycin (Pentostatin ${ }^{\circledR}$ - Tocris) on tachyzoites of $N$. caninum. The amount of 0.8 $\mathrm{mg} \mathrm{mL}^{-1}$ of protein from the parasite was used in order to measure the E-ADA activity. For these tests it was used four concentrations: $10 \mathrm{nM}$, $1 \mathrm{nM}, 25 \mathrm{pM}$ and $15 \mathrm{pM}$ deoxycoformycin. The dose of inhibitor was set in a pilot study and all the tests were carried out in triplicate.

\section{MATERIALES Y MÉTODOS}

Local. El experimento se realizó en el Laboratorio de Parasitología Animal, en la Universidad Federal de Santa María, en la ciudad de Santa María, Brasil.

Neospora caninum aislada. Los taquizoítos de Neospora caninum (NC-1 aislada) fueron dispuestos en un cultivo de células Vero por paso continuo utilizando procedimientos estándar. Los parásitos fueron cosechados a partir de un cultivo de tejidos y se determinó su viabilidad por exclusión de azul de tripano (11), seguido por tres alícuotas en una cámara de Neubauer. Para su inoculación, los organismos se ajustaron a la concentración adecuada ( $1 \times 10^{6}$ taquizoítos $/ \mathrm{mL}$ ). Los taquizoítos fueron lavados tres veces en PBS, ajustados a un $\mathrm{pH}$ de 7.4 y los taquizoítos de NC-1 fueron separados en pellets para el análisis de E-ADA.

Preparación de los taquizoítos. El pellet de taquizoítos fue puesto en una suspensión de 50 $\mathrm{mmol} / \mathrm{L}$ por $\mathrm{mM}$ de tampón fosfato a un $\mathrm{pH}$ de 6.5 para medir la actividad de E-ADA. La concentración proteica de los taquizoítos se midió por el método de Bradford (12) utilizando albúmina de suero bovino como estándar. La concentración proteica en el parásito se expresó como $\mathrm{mg} \mathrm{mL}^{-1}$.

Actividad de E-ADA en los taquizoítos. Para medir la actividad de E-ADA en los taquizoítos de $N$. caninum se utilizó la técnica descrita para evaluar la actividad de E-ADA en formas de tripomastigotos de Trypanosoma evansi (13). En este sentido, la actividad de E-ADA fue medida espectrofotométricamente en los taquizoítos de $N$. caninum mediante el método modificado de Guisti y Galanti (14). Se inició la reacción enzimática agregando $500 \mu \mathrm{L}$ de $21 \mathrm{mmol} / \mathrm{L}$ de adenosina como sustrato y se incubó durante $1 \mathrm{~h}$ a $37^{\circ} \mathrm{C}$. Se detuvo la reacción añadiendo $1.5 \mathrm{ml}$ de 106/0,16 mM de fenol-nitroprusiato a la mezcla de reacción, la cual se mezcló inmediatamente con $1.5 \mathrm{ml}$ de 125/11 $\mathrm{mM}$ de hipoclorito alcalino (hipoclorito sódico) y fue posteriormente sometida a agitación vorticial. El amoniaco liberado reaccionó con el hipoclorito alcalino y el fenol en presencia de un catalizador de nitroprusiato sódico para producir indofenol (color azul), de esta forma la concentración de amoníaco será directamente proporcional a la absorbancia del indofenol a $620 \mathrm{~nm}$. Se utilizó $75 \mu \mathrm{M}$ de sulfato de amonio como el estándar de amonio. Se reportó la actividad específica como U/mg de proteína. Se realizaron tres estimaciones.

Pruebas con inhibidor de E-ADA: deoxicoformicina. En esta prueba se evaluó la acción de la deoxicoformicina (Pentostatina ${ }^{\circledR}$ Tocris) en los taquizoítos de $N$. caninum. Se utilizó $0.8 \mathrm{mg}$ $\mathrm{mL}^{-1}$ de proteína del parásito para medir la actividad 
Statistical analysis. The results of the E-ADA activity on tachyzoites were submitted to analysis of variance followed by Duncan test $(p<0.05)$. The analyses were performed using SAS statistical package (SAS Institute, Cary, NC, USA).

\section{RESULTS}

The pellet tachyzoites of $N$. caninum eluted on phosphate buffer showed a protein concentration of $0.88 \mathrm{mg} \mathrm{mL}^{-1}$, while the E-ADA activity was assessed at concentrations of 0 , $0.2,0.4$, and $0.8 \mathrm{mg} \mathrm{mL}^{-1}$. In this study the presence of E-ADA on tachyzoites of $N$. caninum was detected biochemically, showing that in the lowest and highest concentrations of proteins tested, the ADA activity remained between 0.92 and $1.93 \mathrm{U} / \mathrm{mg}$ of protein, respectively (Figure 1A). Tests with deoxycoformycin on E-ADA activity showed that this inhibitor acts on the E-ADA own of the $N$. caninum. Inhibition of parasite E-ADA activity was directly proportional to the largest concentration of deoxycoformycin used (Figure 1B). de E-ADA. Se utilizaron cuatro concentraciones para estas pruebas: $10 \mathrm{nM}, 1 \mathrm{nM}, 25 \mathrm{pM}$ y $15 \mathrm{pM}$ de deoxicoformicina. En un estudio piloto se utilizó la dosis del inhibidor y todas las pruebas fueron realizadas en tres ocasiones.

Análisis estadístico. Los resultados de la actividad de E-ADA en los taquizoítos se sometieron a un análisis de varianza, seguido de la prueba de Duncan $(p<0.05)$. Los análisis se realizaron utilizando el paquete estadístico SAS (SAS Institute, Cary, NC, EE.UU.).

\section{RESULTADOS}

En el pellet de taquizoítos de $N$. caninum eluido en tampón fosfato se observó una concentración proteica de $0.88 \mathrm{mg} \mathrm{mL}^{-1}$, mientras que la actividad de E-ADA fue analizada en concentraciones de $0,0.2,0.4$ y $0.8 \mathrm{mg} \mathrm{mL}^{-1}$. En este estudio se detectó bioquímicamente la presencia de E-ADA en taquizoítos de $N$. caninum, demostrando que en las concentraciones más altas y más bajas de las proteínas probadas la actividad de ADA se mantuvo entre 0.92 y $1.93 \mathrm{U} / \mathrm{mg}$ de proteína, respectivamente (Figura 1A). Las pruebas con deoxicoformicina en la actividad de E-ADA demostraron que este inhibidor actúa sobre el mismo E-ADA del $N$. caninum. La

A - E-ADA activity in $N$. caninum tachyzoites

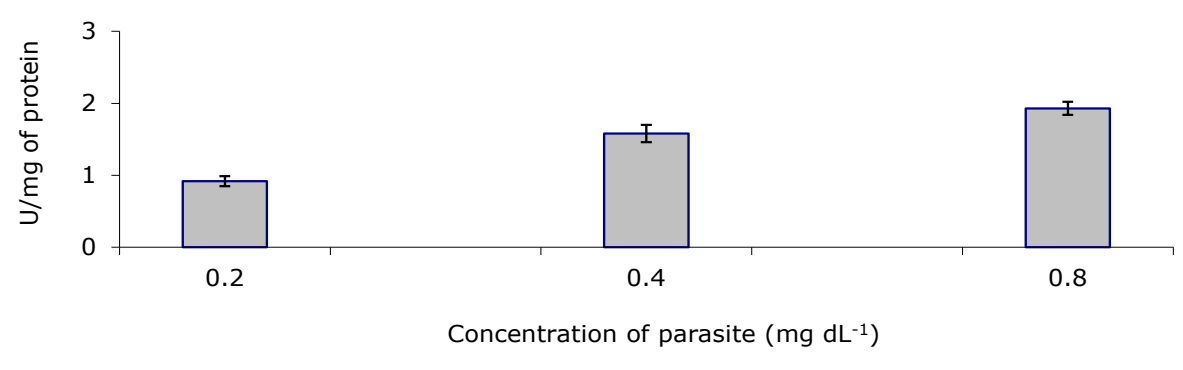

B - Tests with E-ADA inhibitor: $0.8 \mathrm{mg} \mathrm{dL}^{-1}$ of protein in parasite

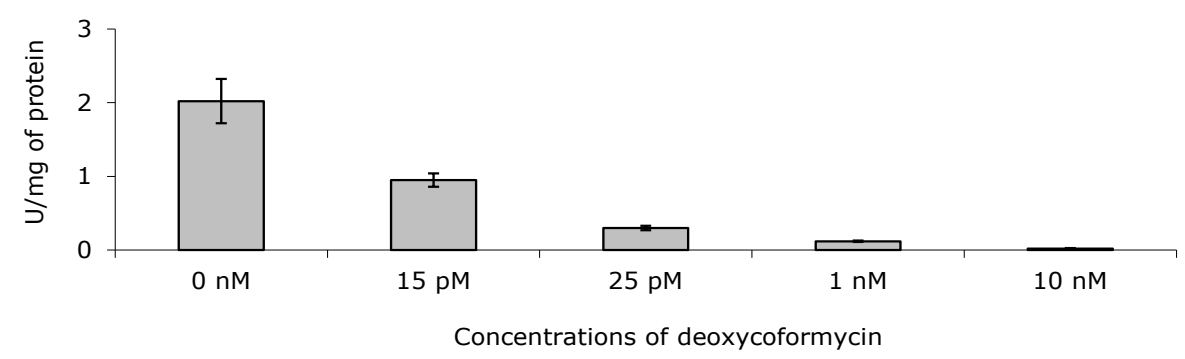

Figure 1. Biochemical detection of adenosine deaminase activity in tachyzoites of $N$. caninum. Relation among E-ADA activity and parasite protein concentration (A) and tests with E-ADA inhibitor (deoxycoformycin) in tachyzoites of N. caninum (B). 


\section{DISCUSSION}

Probably, on the parasite, ADA is in charge of the regulation of adenosine concentration and, consequently, inosine, as occurs in other mammals (9). Our results are corroborated by other studies, for example, using the same method, the E-ADA was detected in trypomastigotes of $T$. evansi (13). Also, according literature, the $N$. caninum tachyzoites express a potent type-I nucleoside triphosphate hydrolase (15), similar T. gonddi. In this sense, it was already demonstrated that $T$. gondii is capable of synthesizing pyrimidine nucleosides (16). Then, purine is needed for the parasite growth, and, for this reason, it must be recovered from the host cell (17), as well as from the protozoa.

Inhibition of E-ADA activity in $N$. caninum was directly proportional to the largest concentration of deoxycoformycin used. This finding suggests the need for further studies, in order to test whether the E-ADA inhibitor may have harmful effect on $N$. caninum, which could bring improvements on how the chemotherapy against this parasite is conducted. In a study with other protozoa, it was observed that when E-ADA inhibitor was only used in the treatment of $T$. brucei in mice, the curative action was not observed and the animals died as a consequence of the disease (18). However, studies showed that the treatment with an adenosine analogue called cordycepin ( $3^{`}$-deoxyadenosine), when protected by an inhibitor of E-ADA, it was effective, showing curative treatment indexes on mice infected with $T$. brucei $(18,19)$. This approach will be investigated in further studies in vivo with neosporosis by our group.

This study allowed us to conclude that the enzyme E-ADA was present in $N$. caninum tachyzoites. We also conclude that the deoxycoformycin tested is able to inhibit the E-ADA detected in this study in parasite, which might be an option for chemotherapy. In this sense, knowing the negative impact of $N$. caninum on reproductive issue (2) in cattle (mainly abortion), might it is an alternative in order to deal with this parasitic infection. inhibición de la actividad de E-ADA del parásito fue directamente proporcional a la mayor concentración de deoxicoformicina utilizada (Figura 1B).

\section{DISCUSIÓN}

En el parásito, la ADA está probablemente a cargo de la regulación de la concentración de adenosina $y$, en consecuencia, de la inosina, como ocurre en otros mamíferos (9). Nuestros resultados han sido corroborados por otros estudios, por ejemplo, utilizando el mismo método, se detectó E-ADA en tripomastigotos de $T$. evansi (13). También, de acuerdo con la literatura, los taquizoítos de $N$. caninum muestran un trifosfato nucleótido hidrolasa tipo-I potente (15), similar a $T$. gonddi. En este sentido, ya ha sido demostrado que el $T$. gondii es capaz de sintetizar nucleósidos de pirimidina (16). Por lo tanto, la purina es necesaria para el crecimiento del parásito y, por esta razón, debe recuperarse de la célula huésped (17) así como de los protozoos.

La inhibición de la actividad de E-ADA en $N$. caninum fue directamente proporcional a la mayor concentración de deoxicoformicina utilizada. Este hallazgo sugiere la necesidad de realizar estudios adicionales con el fin de comprobar si el inhibidor de E-ADA puede tener efectos nocivos sobre $N$. caninum, lo que podría mejorar la manera cómo se lleva a cabo la quimioterapia para este parásito. En un estudio realizado con otros protozoos se observó que cuando el inhibidor de E-ADA fue utilizado en el tratamiento de $T$. brucei en ratones, no observó ninguna acción curativa y los animales murieron como consecuencia de la enfermedad (18). Sin embargo, otros estudios demostraron la efectividad de un tratamiento con un análogo de la adenosina llamado cordicepina ( 3 '-desoxiadenosina) cuando es protegido por un inhibidor de E-ADA, evidenciando indicios de un tratamiento curativo en los ratones infectados con T. brucei $(18,19)$. Este enfoque será investigado por nuestro grupo en estudios posteriores in vivo con neosporosis.

Este estudio nos permitió llegar a la conclusión que la enzima E-ADA estaba presente en los taquizoítos de $N$. caninum. También concluimos que la deoxicoformicina ensayada es capaz de inhibir la E-ADA detectada en el parásito en este estudio, la cual puede ser una opción para la quimioterapia. En este sentido, al conocer el impacto negativo de $N$. caninum en la producción y reproducción bovina (2) (principalmente aborto), puede constituir una alternativa para tratar esta infección parásita. 


\section{REFERENCES}

1. Dubey JP, Schares G, Ortega-Mora, LM. Epidemiology and control of neosporosis and Neospora caninum. Clin Microbiol Rev 2007; 20(2):323-367.

2. Larson RL, Hardin DK, Pierce VL. Economic considerations for diagnostic and control options for Neospora caninum-induced abortions in endemically infected herds of beef cattle. J Am Vet Med Assoc 2004; 224(10):1597-1604.

3. Goodswen SJ, Kennedy PJ, Ellis JP. A review of the infection, genetics, and evolution of Neospora caninum: From the past to the present. Infect Genet Evol 2013; 13:133-150.

4. Weston JF, Heuer C, Williamson NB. Efficacy of a Neospora caninum killed tachyzoite vaccine in preventing abortion and vertical transmission in dairy cattle. Prev Vet Med 2012; 103(2-3):136-44.

5. Quinn HE, Miller CMD, Ellis JT. The cell-mediated immune response to Neospora caninum during pregnancy in the mouse is associated with a bias towards production of interleukin-4. Int J Parasitol 2004; 34(6):723-732.

6. Ellis J, Sinclair D, Morrison D, Al-Qassab S, Springett K, Ivens A. Microarray analyses of mouse responses to infection by Neospora caninum identifies disease associated cellular pathways in the host response. Mol Biochem Parasitol 2010; 174(2):117-127.

7. Reid AJ, Vermont SJ, Cotton JA, Harris D, HillCawthorne GA, Könen-Waisman S, Latham S. M. Comparative Genomics of the Apicomplexan Parasites Toxoplasma gondii and Neospora caninum: Coccidia Differing in Host Range and Transmission Strategy. PLoS Pathog 2012; 8(3):e1002567.

8. Kato K, Sugi T, Iwanaga T. Roles of Apicomplexan protein kinases at each life cycle stage. Parasitol Int 2012; 61(2):224-234.

9. Desrosiers MD, Cembrola KM, Fakir MJ, Stephens LA, Jama FM, Shameli A, Mehal WZ, Shi Y. Adenosine deamination sustains dendritic cell activation in inflammation. J Immunol 2007;179(3):1884-1892.

10. Dalla-Rosa $L$, Da Silva AS, Ruchel JB, Gressler LT, Oliveira CB, França RT, Lopes STA, Leal DBR, Monteiro Silvia G. Influence of treatment with 3--deoxyadenosine associated deoxycoformycin on hematological parameters and activity of adenosine deaminase in infected mice with Trypanosoma evansi. Exp Parasitol 2013; 135(2):357-362.

11. Johnson S, Nguyen V, Coder D. Assessment of cell viability. Curr Protoc Cytom 2013; 9(9.2): 10.1002/0471142956.cy0902s64.

12. Bradford MM. A rapid and sensitive method for the quantitation of microgram quantities of protein utilizing the principle of protein-dye binding. Anal Biochem 1976; 72(1):248-254.

13. Da Silva AS, Pimentel VC, Jaques JA, Wolkmer $P$, Tavares KC, Lazzarotto CR, Miletti LC, Schetinger MR, Mazzanti CM, Lopes ST, Monteiro SG. Biochemical detection of adenosine deaminase in Trypanosoma evansi. Exp Parasitol 2011; 128(3):298-300.

14. Giusti G, Galanti B. Methods of Enzymatic Analysis. $3^{\text {rd }}$ ed. Verlag Chemie. Weinheim, Germany, 1984.

15. Asai T, Howe DK, Nakajima K, Nozaki T, Takeuchi T, Sibley LD. Neospora caninum: tachyzoites express a potent type-I nucleoside triphosphate hydrolase. Exp Parasitol 1998; 90(3):277-285.

16. Fox BA, Gigley JP, Bzik DJ. Toxoplasma gondii lacks the enzymes required for de novo arginine biosynthesis and arginine starvation triggers cyst formation. Int J Parasitol 2004; 34(3):323-31.

17. Chaudhary K, Darling JA, Fohl LM, Sullivan WJ Jr, Donald RG, Pfefferkorn ER, Ullman $B$, Roos DS. Purine salvage pathways in the apicomplexan parasite Toxoplasma gondii. J Biol Chem 2004; 279(30):31221-31227.

18. Rottenberg ME, Masocha W, Ferella M, PetittoAssis F, Goto H, Kristensson K, McCaffrey R, Wigzell $\mathrm{H}$. Treatment of African trypanosomiasis with cordycepin and adenosine deaminase inhibitors in a mouse model. J Infect Dis 2005; 192(9):1658-1665.

19. Vodnala SK, Ferella M, Lundén-Miguel $H$, Betha E, van Reet N. Preclinical Assessment of the Treatment of Second-Stage African Trypanosomiasis with Cordycepin and Deoxycoformycin. PLOS Negl Trop Dis 2009; 3(8):e495. doi: 10.1371/journal.pntd.0000495 